\title{
COMPARATIVE ANALYSIS OF THE DECORATED ARRAIES WITH GEOMETRIC AND PLANT MOTIFS IN ARCHITECTURE OF THE GRAND MOSQUE OF YAZD AND THEIR DEVELOPMENTS
}

\author{
Mona Abdullahi Hanifi \\ Master of Architecture, Yazd University \\ Arian Maleki \\ Master of Architecture, Islamic Azad University
}

\begin{abstract}
The decorations used in traditional and Islamic arts have always had a special place. These decorations in a way reflect the ideas of the artists, the customs and traditions of each region. The expression of these ideas happens in such a way that they are not separated from each other, but we see the effects of one over the other in various arts. In the meantime, Yazd region, in turn, has been the scene of various arts which have been formed together with the impact of specific thoughts of the region. One of the distinctive features of Islamic art are its decorations that reaches its peak at a certain stage of development and becomes especially important, as each has an effect on the others and some sparks of this effect is evident in the samples of art. This issue can be significantly observed in the artwork a certain area whose artists have the same ideas. The architectural decorations in various parts of the country, especially in desert areas are of particular importance and are directly related with attitudes and needs. That's why the mosque in Yazd, Yazd is one of the oldest examples of religious architecture with a variety of geometric and plant tiling with beautiful and unique structural and decorative elements of the array. Thus, the present study study is a comparative analysis of the decorated arraies with geometric and plant designs in architecture of the Grand Mosque of Yazd and their developments. This study with historical analysis method examines the historical documents, bibliographical resources and field studies to collect data, and after analysis and summarizing, it is concludes about the changes in the method of implementation (the Brick molding and color Tile) and a form of semantic content (natural plant motifs and arabesques and complex geometric shapes). Further, the decorative structure changes with calligraphic lines used in the mosque is used in the course of their analysis.
\end{abstract}

Keywords: Decorative array, Islamic architecture, geometric and plant motifs, tiled, Yazd Great mosque

\section{GRAND YAZD CAMİ VE GELISMELERİN MIMARIDE GEOMETRİK VE BITTKISSL MOTIFLI SÜSLENMIŞ DİZILERİN KARŞILAŞTIRMALI ANALIZI}

ÖZ

Geleneksel ve İslam sanatlarında kullanılan süslemeler her zaman özel bir yeri vardı. Bir şekilde bu süslemeler her bölgenin sanatçıların fikirlerini, örf ve geleneklerini yansıtmaktadır. Bu fikirlerin ifadesi bunlar birbirinden ayrılmış değildir böyle bir şekilde olur, ama biz çeşitli sanat diğer üzerinde birinin etkilerini görüyoruz. Bu arada, Yezd bölgesi, sırayla, bölgenin belirli düşüncelerin etkisiyle birlikte oluşmuş çeşitli sanatların sahne olmuştur. İslam sanatının ayırt edici özelliklerinden biri birbirlerinin üzerinde bir etkisi vardır ve bu etki bazı kıvılcım sanat örneklerinde açıkça görüldüğü gibi, gelişmenin belli bir aşamasında zirveye ulaşır ve özellikle önemli hale onun süslemeler vardır. $\mathrm{Bu}$ sorun önemli ölçüde resimdeki olan sanatçılar aynı fikirleri var belirli bir alanı görülebilir. Özellikle çöl alanlarında ülkenin çeşitli yerlerinde mimari dekorasyon, özel bir önem ve doğrudan tutum ve ihtiyaçları ile ilgilidir. Yazd cami, Yazd dizinin güzel ve eşsiz bir yapı ve dekoratif 
elemanları ile geometrik ve bitki döșeme çeșitli dini mimarisinin en eski örneklerinden biri olmasının nedeni de budur. Bu nedenle, bu çalışma Çalışma Büyük Yazd Camii ve gelişmeler mimarisinde geometrik ve bitkisel tasarımlar ile dekore arraies karşılaştırmalı analizidir. tarihsel analizi yöntemi ile bu çalışmada veri toplamak için tarihsel belgeler, bibliyografik kaynak ve saha çalışmalarını inceler, analiz ve özetleme sonra, uygulama yöntemine (Tuğla döküm ve renk Çini) değiş̧iklikler ve semantik bir form hakkında son bulur içeriği (doğal bitki motifleri ve arabesk ve karmaşık geometrik şekiller). Ayrıca, Camide kullanılan kaligrafik çizgiler ile dekoratif yapı değişiklikleri kendi analiz sırasında kullanilır.

Anahtar Kelimeler: kiremitli Dekoratif dizi, İslam mimarisi, geometrik ve bitkisel motifler, Yazd Büyük cami

\section{INTRODUCTION}

In the decorating architecture, each motif over its face value has the value derived from the culture and expresses opinions and continued aspirations of the people in a generation. However, architecture arraies, on one hand, call the viewer into the beautiful superficial motifs and spaces of the building including the motifs on the walls and on the other hand open the perspective of the viewer to the territory covered by the concepts of cultural and religious secrets and motifs. Culture and traditional art of architecture in Iran, had been transferred visually and through personal training and imitations.Decorations in Islamic art and architecture are used as a tool in the hands of unknown artists of the territory in order to achieve the objectives of the beliefs of the Muslim community. The decorations especially in mosques and religious places had magnificent beauty and unity. In this article we have tried to enumerate and analyze the decorated motifs in the architecture of the mosques in Iran by a Comparative analysis of the decorated arraies with geometric and plant motifs in architecture of the Grand Mosque of Yazd and their developments. Given the above, this research seeks to answer the following basic questions:

- What are the characteristic style of architecture and more specifically the interior decoration of the Grand Mosque of Yazd?

- What are the most important decorative arraies in the motifs of the Grand Mosque of Yazd?

- What changes have been made in the geometric, plant and structural motifs and decorative calligraphics of the Grand Mosque of Yazd?

\section{RESEARCH METHOD}

In this study, it is tried to first examine and analyze the decorative arraies in the architecture of the mosques using the historical interpretative method in a case study using the samples available and then the evolution of the decorations in the mosquearchitecture will be reviewed. For this purpose Grand Mosque of Yazd will be compared and examined by reviewing the related literature as well as field studies so that the unique features of architectural and decorative elements in the mosque are focused. The basic data of the present research was collected through biblical and field studies and due to lack of information, most of the data has been collected and written based on the architectural remains of Great Mosque of Yazd as historical documents.

\section{ANALYSIS OF THE DECORATIVE ARRAIES IN THE ARCHITECTURE OF THE MOSQUE}

Mosque is an excellent example of Islamic building and is the key of the Islamic and is bult in such a way that it is sustainable. The mosque made the Muslim creators familiar with the pre-Islamic architectural heritage; reporting about the Mosque that is considered as the major portion of the Islamic architecture is not complete without speaking about the beautiful decorations that adorned it makes. In previous religious atmosphere, certain conflicts of Muslims with picture decorations associated with idolatry encouraged the architect to intensly focus on abstract decorating which is considered as a value in order to help the thinking and it was because of this tha all the time was spent on floor of the mosque decorative plates which were in the sight of people sitting on the floor. Generally, Islamic architectural decoration has two dimensions of application (material) and 
conceptual (semantic). In the Application, the type of materials, tools, implementation methods, size, location and venue and physical quantities are consider that has always been concerned and artists by enjoying the creativity, experience and solutions executive Technical managed over the centuries, more and more beautiful and more fully develop the field of architectural decoration. The most important part of decorating is both semantic and conceptual aspects that have attracted hundreds of Muslim and non-Muslim thinkers. In this connection, there are different opinions and different views; In this way, "Titus Burckhardt" believes that these designs have historical, mystical and thoughtful naturs and represents unity in diversity and diversity in unity. Also, "Oleg Grabar" refers to the animating of ornaments but states that decorations do not have any intrinsic meaning and cultural dimension and are solely for decoration and admire; they are just found simulating meaning in inscriptions, that's why he considered them as purely decorative designs and lacking the spiritual and symbolic dimension.

"According to him, decorations are composed of the mediums on one hand and its observant on the other hand. Arraies are filters through which the pleasures messages and symbols, perhaps even consciously or unconsciously are taken to establish communication with the audience in the best way »(Grabar, 1992: 39). Another researcher has stated that the architectural ornamentation and the application aimed at the individual and the elimination of material, denial of voluminous masses and replace them with something that is more palpable and tangible, yet. It is the fact that its forms will change even when they want to look at them carefully and is obtained by the repeat mode with single units for infinity. In short, so far in this field is often conflicting views look like mystical and comment on aspects of ambiguity and uncertainty and fear of a vacuum, has been proposed. But what has been agreed by most researchers in this field, namely non-material aspects of their personal and otherwise, so decorative, symbolic forms of Islamic art in addition to various aspects of science, Islamic architecture are manifested in a way to understand that aesthetic designs in mosques as symbols of Islamic culture was aware of the need to code. However, the "Islamic decorative art, to express the sacred space" and Islamic artists are always trying to push the matter to the realm of meaning because essentially "Art in the Islamic vision honor and glory and beauty of Iranian architecture especially in the Islamic era depends to decoration and ornaments. Islamic sublime art of decorative and applied arts, to build the most beautiful religious buildings has special significance. Decorations such as brickwork, stucco, tiling, carvings, wood carvings, mirror work and paintings have been prevalent in all Islamic eras and have developed its facilities in any period of time. Architectural decorations by the Persians, was a major artistic evolution, so that in many Muslim countries by Iranian artists, decorated with different structures, these buildings run over time and with different techniques and specific courses in each country.

\section{A REVIEW OF THE MOSQUES AND ISLAMIC DECORATIONS IN THE}

\section{ARCHITECHURE}

Islamic sublime art is one of the decorative and applied arts to build the most beautiful religious buildings have a special significance. Decorations such as brickwork, stucco, tiling, carvings, wood carvings, mirror work and paintings in all Islamic eras have been prevalent in any period of time and have developed with its facilities. Architectural decorations by the Persians was a major artistic evolution, so that in many Muslim countries by Iranian artists have decorated with different structures, these buildings run over time and with different and specific techniques courses in each country.

Gradually some of the array is deleted or replaced by another. Mosque as a specific place for prayer has a special architecture from the beginning of Islam and it has a variety of architecture in different historical periods, however, in modern times, its architecture changed and gradually some elements and arrays were removed or altered.

In Nahja Alfasahe, it is stated that: "The mosques are the most favorite places for God." So we can say that the mosque as the most popular places in the city for God is the heart and center of the cities and all look at them. In this connection, the Islamic city will be determined by the prospect of mosque. Islam's emphasis on purity and cleanliness, picking up the decoration of mosques and 
attention to beauty is considered as a natural human tendency attributed to God. This inclination, have prompted Muslims to mosques or Islamic in the hearts of Muslims in its heart and soul beats, home to the hearts of the faithful and the sign of God on earth (Ka'bah) makes the soul of Muslims pure and the holy (Ansari, 2002: 69).

\section{MANIFESTATIONS AND EFFECTS OF THE ARCHITECTURAL DECORATIONS IN THE PHYSICAL ARCHITECTURE OF THE MOSQUE}

In Iran in all periods, three types of decorative brickwork, stucco and tile on mosques were used (Hill and Grabar, 1996: 103). In terms of duration of use and the spread of the decorations, each of these three types, with two other marks and matches, for example, decorative brickwork in the Seljuks came before (Wilber, 1376: 85). Brilliant use of brick where brick complete sentence with a stunning power of a decorative element is related to the 5th and 6th centuries AH (Kayani, 1997: 33).

\section{BRICK WORK}

Brick is a Babylonian term and was the name of the Clay on which the Charter command but wrote them. Brick stone transformed the clay cooking is obtained and the brick to the civilizations of Mesopotamia, including the Sumerians and Babylonians are compared. There are good reasons to choose bricks from the Iranians that including the cases mentioned that the rock is more stable, less expensive, quickly building work and allow for flexibility, and soon reveals most effective physical forces, accordingly. The potential beauty of the brick is also notable for decoration. Continueing the use of brick in Iran after the Islamic architecture of the era led to the "module" or measure of Iranian architecture in terms of fitness and beauty, but also transformed the static aspects and provide the opportunity to create beauty in low-volume sites and remote locations are made desert. In the postIslamic era, the first examples of brickwork from the laboratory and the columns of the nave mosque belongs.

And in general, from the second century up to the beginning of the fifth century may be called the period of formation and development of Islamic architecture brickwork. In general brick fortifications and used mostly in pre-Islamic period, but after Islam while having a strength aspect, also finds decorative aspects. Over time, the use of brick in the mosque, is quite evident. Use it to culminate in a tenth-century decorated and luxurious at the same time for plaster or decorative boxes also provided infrastructure. Surrender to refinish plaster, stucco designs to best encourage growth and the end of the twelfth century saw the realization of this potential in the bed was large altars. Mysterious miracle made and baked bricks made of soil, provoke our feelings because the brick represents civilization, emotions, culture and taste, and with the United Nations Human stepped interface between generations and of the Persians than any nation Brick worked, experienced and have been in various aspects of structural and aesthetic use.

\section{MOLDINGS}

Archaeological evidence indicates that prior to the date of manufacture of molded clay bricks and bakes it. The oldest building in the world, the Pyramids of Egypt, datied back to four hundred years where the resistant adhesive plaster as a plinth after the stones have been used to coil them. One specific application of plaster, stucco plaster walls and interior surfaces of buildings and art, this adornment to the fullest extent and take agreeable. Applying plaster ornaments decorate the walls, common practice in Iran and Iraq. The first people who began this work in Iran, Achaemenid and Sassanid and then the Arabs during their conquest, they learned this art. Iran has long been an element of the "cast" is familiar and plaster works in Haft Tappeh in Khuzestan discovered that the Elamite civilization is approved. Parthians and Achaemenid certainly have been familiar with this element and manufacturing technology of plaster ornaments. The modling of Mount Khwaja bed in southeastern Iran is related to the Parthian civilization. Consequently, in the glorious age of Islam in mosques, schools and old Amamzadhhay imported and four porch arches, domes and Srdrhay Islamic term was magnificent. Use the bed for the first time in Iranian art and can be seen in the Parthian period. In general, the use of gypsum plasters and has a long history in Iran. With the spread of Islam in various designs such as "Arabesque" and "Angelica" was used to decorate mosques, schools and resulting in 
bed until the Mongols of the best projects and maps were used. Therefore, before the introduction of tiling, plaster and decorate only the beauty of monuments and religious places. Mosques of Isfahan indicate the burgeoning growth in the arts. With the introduction of the Safavids of the bed only when used indoors nobility and the use of chalk continued to reign.

\section{TILING}

Tile is one of the pleasant ways of architectural and decorative elements in all the land of Islam. Tiles of foreign elements in the development of small colored brick facades to begin and complete coverage of the monuments erected in the eighth and ninth centuries AD led. In the land of the West in the Muslim world who are basically building stone, bright colorful tiles on the walls of gray stone buildings tenth and eleventh century Turkey, the effect is completely different but harmonious and they make you feel, like other Iranian arts in the Islamic era, the tile industry what is also of great prestige. At the end of the second millennium BC, the Iranian artists, who were making bricks and glazed brick and the makeup of its buildings was confirmed. During the reign of the Achaemenid and Sassanid palaces also make the use of colored glazed brick was being accomplished. Gradually, the art of tile work in the Islamic period began with the new method. Many researchers believe that Iran is the first country tiling as both the makeup and the strength of the bull and almost at the end of the 4th century AD onwards, the materials can be found under the tiles is not up. Tilings as well as covering are the other heritage of the decorative elements of the covenant of Fatimid Egypt. An important component of the tile, glaze the glass-like surface that is both decorative and functional performance. Glazed tiles decorated with tiles are not only the richness of the architecture, but also as insulation for building walls against moisture and water act.

\section{MOGHARNAS}

Mogharnas need to know to understand its literal meaning. Mogharnas ladders made of swords on board, the Arabic building that has been painted, the building the base and sides of the roof and around the Persian, the deer say. Derived from Arabic, tall monument porch adorned and decorated with circular forms and motifs on the base of the stairs, part of the stucco decoration in the room and the porch in different ways. Featured stucco house on the eve of the deer, colorful things and a helmet and also states that: Mogharnas is accompanied by curves and strips and broken line and it can be can said something is curve and strip shaped with decorative element that we have raised and depressed levels of a number of more or less carried, agrees. The mountains and the floor is empty and horizontal floors. Mogharnas is a decorative element that was even before Islam. But it should be noted that the pre-Islamic Mogharnas Mogharnas Islam after striking differences are evident. Mogharnas is an application in advance of Islam into two main periods, namely BC 250 to $224 \mathrm{BC}$ and from $224 \mathrm{BC}$ until the advent of Islam are known. It should be noted, however, that the examples in $550 \mathrm{BC}$ has been in the field. After the arrival of Islam in Iran, Iranian art, while maintaining its historical background, also were divine aspect. In the meantime, Mogharnas is considered as other original artwork and a familiar figure in the Islamic era. The Mogharnas in the first four centuries of Islam, the period can be found sporadically. For example, the tomb of Ismail Samani of the third century AH in Bukhara, which has a simple baseboard on the walls and on the top and bottom rows of arcades and Mogharnas a stupa at the bottom Gvshvarhay. In the Fatimid era in Egypt, the Egyptians borrowed Mogharnas from the Persians and the tombs of their elders was used.

\section{DESIGN AND MOTIF OF THE MOSQUE IN YAZD}

The Great Mosque of Yazd, without doubt one of the masterpieces of Islamic architecture is innovative and unique decorating beautiful, admirable as it has effect.

It consists of a high porch, domes and two yard in the summer on the sides, two incubated in the eastern and western sides, a large rectangular courtyard and two fleeting. Founder of the the first building in the eleventh century AH was Amir Ala Kalyjar, the first Kakouei Amir, but the current building of the mosque was found by Sayyid Rukn al-Din Mohammad Ghaziin the construction of the fourteenth century. The most beautiful parts of the building can be set and the area around it called Ivan and dome home. View high porch of the mosque, with a collection of the most beautiful arabesque mosaic tiles with herbal and Chinese knot covered. The decorations along with 
percussionist bricks, tiles, mosaic tiles and Kufi inscriptions, have created a stunning collection of original and acclaimed motivates the viewer (Hajighasemi, 2004: 16). Cover the entire interior and exterior surfaces with decorative motifs and inscriptions in various forms, not only fanciful design of buildings in the paintings of the time, but in painterly style architecture reflects the following discussion will be addressed. Beautiful designs mosque in Yazd, according to research carried out, is unique in its kind and as mosques, including plant designs like arabesques, Shah Abbasi flowers, flower motifs, etc., geometric patterns, and Chinese knot, motifs, inscriptions and paintings line (Chitty, 2001: 18). Brick and tile decorating an important motif in Yazd Mosque and context are important decorative motifs are included in the building in its place. It's a bricklayer in conventional methods and are pointed after the bricks, the main decorative materials, has been decorated with tiles. Tile designs in this building, mostly geometric, plant, and combination and composition with calligraphic lines (inscription) is. Inscription in the decoration of mosques, especially the dermis comprehensive especially in Great mosque of Yazd very important because aside from decorative and cosmetic aspect of the building, in terms of religion is also important and can be a lot of unknowns about the features of the art courses or special materials make clear (Zamani, 1993: 12). Colors used in the Mosque of Yazd, like other mosques and religious places is determined. Tile is one of the decorative style of the mosque is the largest of its color. Colors used in all levels of the mosque, including turquoise, blue, white, black, crimson, green, orange and brown (Chiti 2001; 19). Christmas color variety of decorative motifs of plants, turquoise, blue, white and other colors like orange if comes first, black, brown and green are secondary.

The number of colors used in the mosque geometric designs, like plant motifs. According to the dried and geometric motifs and diversity of those little colored surfaces, color and form geometric patterns are set as a supplement along with other elements of the fall. In more simplistic in form and color contrast geometric designs, creating a different atmosphere in the decorative elements of the Mosque of Yazd. Confining (frame) narrow with simple geometric designs and intense contrasting colors (turquoise, blue and white) makes the levels attractive.

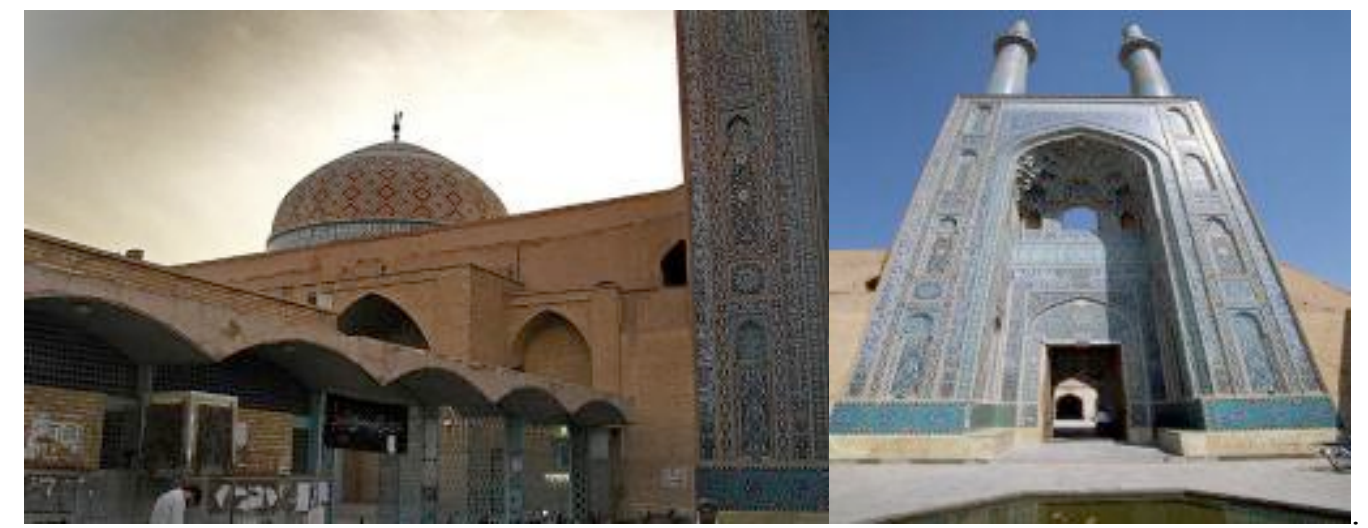

Figure 1: Great Mosque of Yazd

THE DEVELOPMENT HISTORY OF THE SECOND HALF OF THE THIRD CENTURY AD The current mosque was built over the centuries instead of three mosques were built next to each other. They eventually became the Qajar to the mosque unit with large foreground. The first mosque or "Old Mosque" in the second half of the third century AD and was built during the reign of Amr ibn al-Layth Safari with porch. The narrative parsley on the mosque in Yazd, Yazd and later on the new comprehensive transportation is good, Sasanian fire took place. The mosque in the second half of the fifth century $\mathrm{AH}$, during the reign of rulers Kakouei Yazd, repair and modernization, and in the vicinity of the minaret was built to the ninth century AD was established. Early works to 1324 AD mosque in the northeast of the mosque remained current. The second mosque, or "old mosque", in the second half of the fifth century AD during the reign of Ala al-Dawla was made Gushtasp Ben Ali Ben F. Prince Kakouei Yazd. The mosque has a dome house and one or more of the porch, in the western part of the Old mosque was founded, and then F. Ben Ali Kakouei girls, bedchamber and a tomb in 
the vicinity of the building. The mosque was built by the year $1240 \mathrm{AH}$ and this year in the modernization and expansion of the building, much of it was destroyed. The third mosque or "New Mosque" in the first half of the eighth century AD by the "Roknaddin Mohammad Ghazi," the man behind the old mosque was founded. This small mosque and dome foreground and a large porch. In the late eighth and early ninth century during the reign of al-Muzaffar mosque had many changes. In the year $777 \mathrm{AH}$ Yahya al-Muzaffar Shah structural measures to decorative tile work and the construction of a large new mosque in the eastern courtyard and entrance led to a huge mosque. In the year 809 AD and took a "eunuch Jalal al-Din al-Khwarizmi" New Mosque continued decorative tile work. At this time, inscriptions chapter "Ana Fthna" of about a square yard and porch and dome of the mosque began in the year $819 \mathrm{AH}$, al-Din Shah of Kerman, coinciding with the construction of the western nave and west input port, the respectively. In the reign of Amir in the year $825 \mathrm{AH}$, repair and renovation of the mosque began in the year $846 \mathrm{AD}$ lasted Old. The architectural style of the Azeri and Shah Rukh, long entrance of the mosque was built. In the manner of Isfahan in the Safavid period, the Shah Tahmasp two minarets were added to the entrance. Fath Ali Shah Qajar period, the broad construction of the mosque, the mosque led to the destruction of many parts of the building Tuesday. The extension of the period of construction of the mosque porch in the west, an area of 1008 square meters in the year $1240 \mathrm{AH}$. At this time, the current mosque, a building unit was formed.

\section{MATCHING THE COLOR AND DECORATIVE ARRAIES IN THE MOSQUE IN YAZD}

Review of the way in mosques can classify them by subject and content (plants, geometric, calligraphy, and architecture), location (altar, dome, porch, etc.) by way of run (bed, tiling, brickwork) is different. In this paper, the main arrays used in decorative motifs were used in the construction of the Mosque of Yazd. It should be noted that due to limitations in the mosque decorative paper other providers, such as stucco, brick Mogharnas and has not been studied in detail and starlings in the form of decorative motifs to explore the array has been paid. For this purpose, geometric designs, including designs rhombus tiling in three groups, triangle (Congress), square (tamarind), broken lines, crux and Shms $h$ eight and plant parts, including eight goals, arabesques, altar and flower structures and Finally array of decorative calligraphic lines due to the similarities or differences between the tile and on the type of application being used and their place have been been investigated.

\section{GEOMETRIC ARRAYS}

Often repeated to the infinite geometric arrays based on simple models of identity are the basic shapes such as squares, circles and polygons were formed and symbolic concepts of philosophical and cosmic connected. In each of these repeating units, observant eyes directed toward the center (centralization), but surface that numerous repetitions of motifs, it can be prevented that the mind is focused on the specific case. According to Burckhardt (1986: 79) geometric design from focusing on one place and thus precludes sensuality, both logical and well proportioned, and this is the perfect manifestation of the human spirit.

Mosque in Yazd geometrical structure of the array to show the context for the plant motifs and inscriptions provided. Pentagons (Fig. 2), seeds and square (Figure 3), eight and four TB (Figure 4) and geometric ornamentation, including the manner of bed in the margin of the altar and performed the adjacent columns to be included. On the arches of the middle hall, there are some arrangement of bricks with simple geometric designs (Fig. 5). 


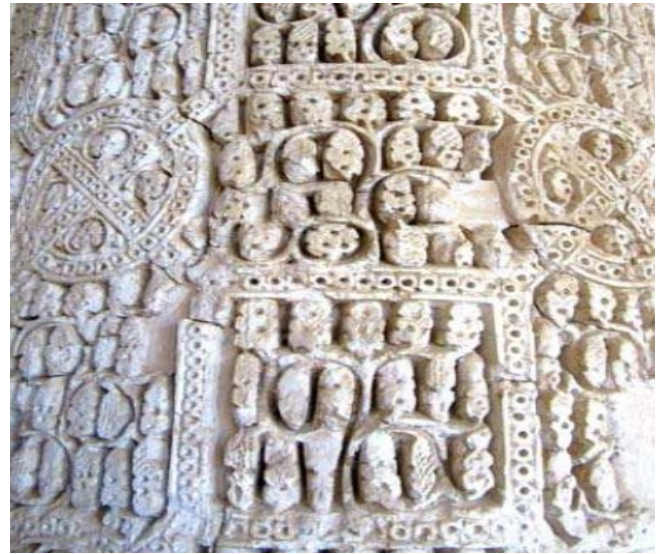

Figure 3. Seeds and squares motifs in the adjacent column of the mosques

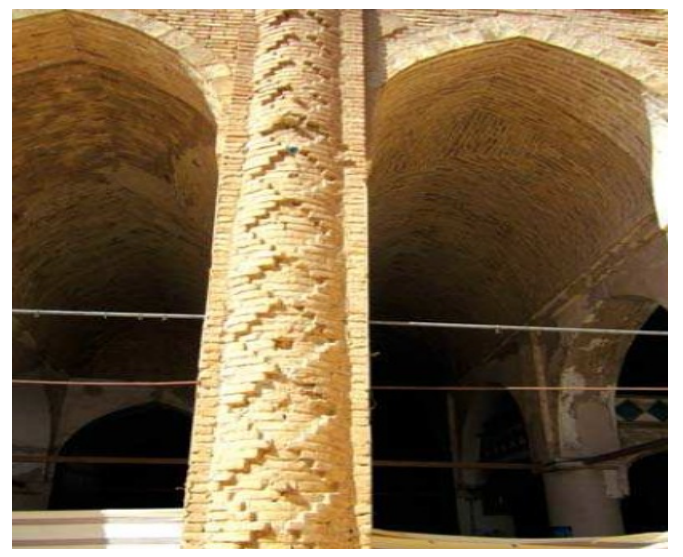

Figure 5: Chinese brick diamonds in the spray mosque

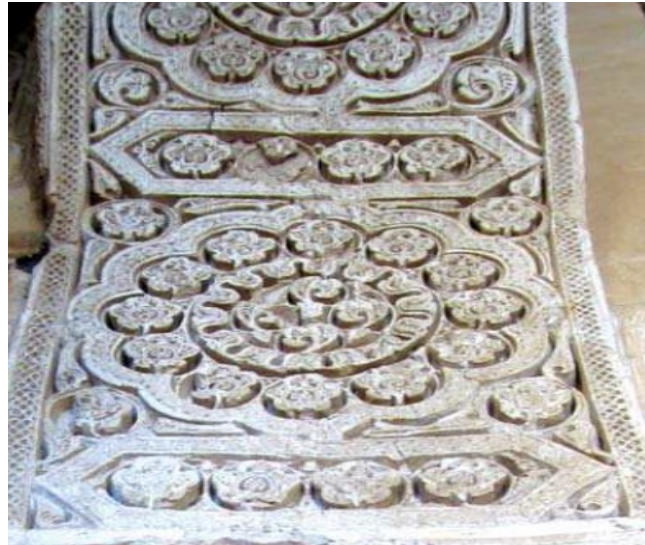

Figure 2: irregular hexagon adjacent to the arc of mosques

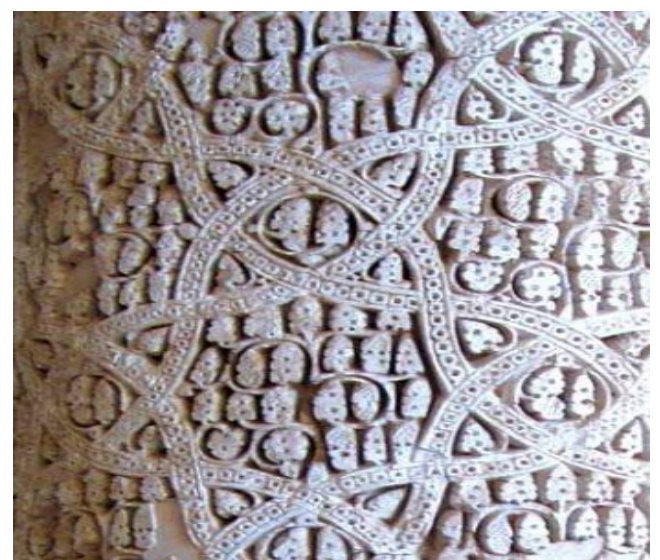

Figure 4 patterns of TB in the eight and four columns adjacent mosque

A motif that has been used in tiled mosque in different ways, the motif of the diamond. This motif has been of great use in brickwork pottery. The diamond implemented in different ways and according to the location and position in the tiled mosque, which used different names. Sometimes the original text, sometimes on the edge of the tiles with a simpler plan has been implemented. Among them, the motif Citron named in the original woven tile and white and blue design is mainly in two forms. A similar example of this motif can be seen in the dome of the mosque in Yazd (Figure 6). How the implementation of the dome, a combination of brick and tiles are rectangular, with close ties to the more specific motif in the tile, with the difference that in the dome, brickwork and motif fields, in two colors, cyan and black work. Given that this part of the building was owned by the late patriarch, type, shape and materials used in the dome, the style have continued the Seljuk period (Kiani, 1997).

Another example is the diamond Tile has two rows of chain. The motif of the chain can encompass the entire text blocks an example of the motif of the mosque has been used in several places. Especially in the interior of the dome in the Karyhay Mogharnas under the dome that is widely used in the designs and materials lines (Figure 7). That the dome that was built by the Seyed Rokn andin, as well as the influence of artists in tile decorations used in architectural specifies. A similar combination of the diamond, the lower edge of the dome of the mosque there by brick tile color on a white background (outside the building) and the combination of blue tile and brick (in the interior of the building) can be seen. The combination of four diamonds together his new motif created to dislodge the books, the name of Allah to the building line and has created a beautiful azure color effects (Figure 8). On the sidelines of the dome of the mosque, combined diamond that has created an independent motif as well as narrower margins as well as chains of the diamond so that the motif of "margin" by famous and architectural motifs. An example of this motif on the sidelines of a thin chain 
around on the tiled entrance frames mosque with Arabesque designs is implemented. The difference is that the diamond is a diamond in the spline is not a size between large and small, with mosaic tiles in white, blue and brown have been implemented (Figure 9).

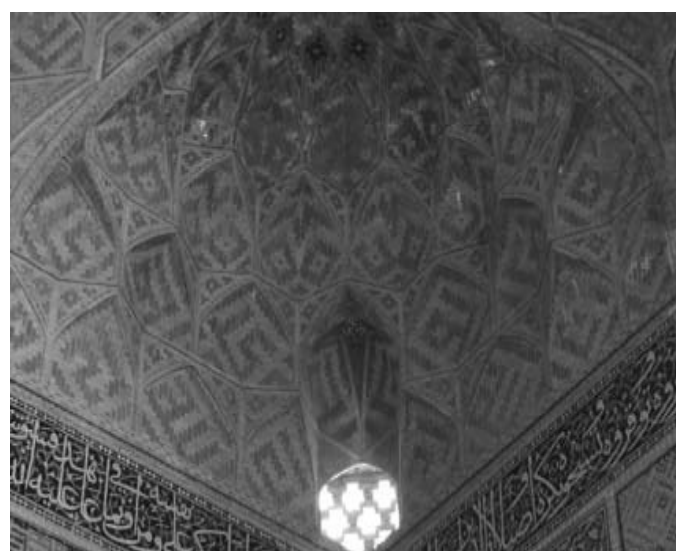

Figure 7: The motif of diamonds, Mogharnas in the space under the dome, Mosque

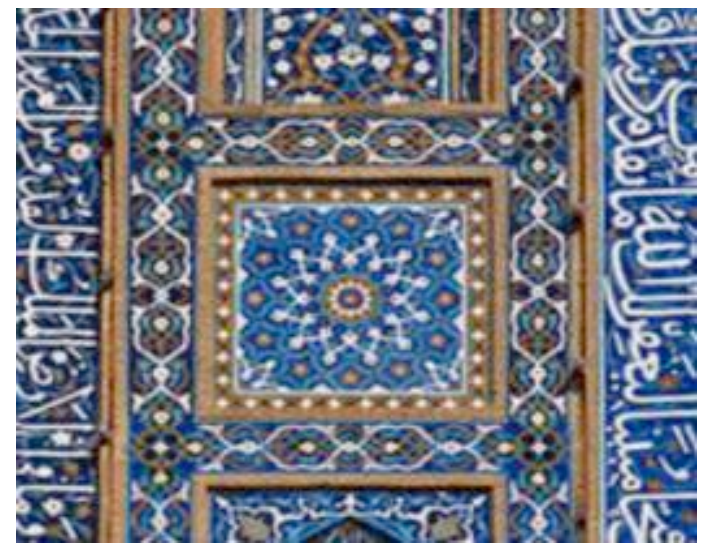

Figure 9 : small diamond motifs, tiled entrance of the Great Mosque

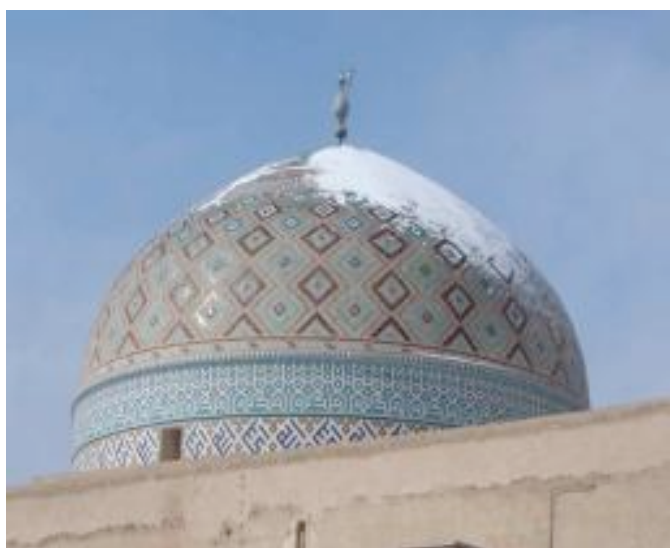

Figure 6. The motif of the diamond, dome, mosque in Yazd

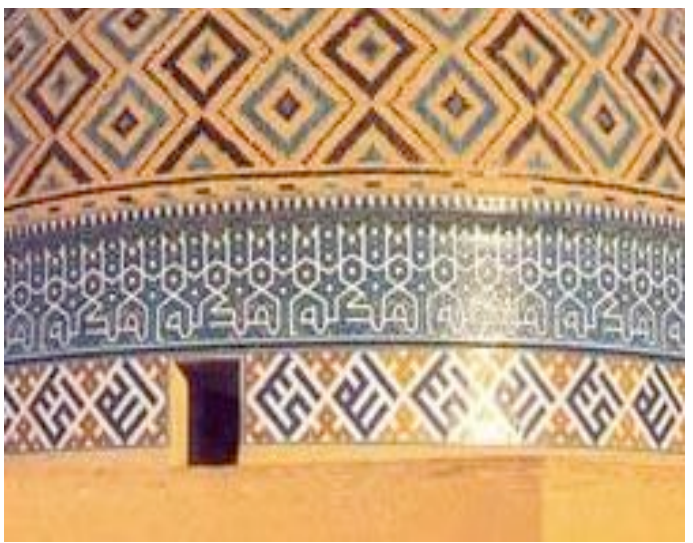

Figure 8: The motif of diamonds, margins tiled dome, Mosque

Based on what was said about the motif of diamonds, this motif will have many applications in the processing tile and the inclusion of this motif together has caused hybrid and more complex designs of diamond, each of which have different names. Among the motifs in tile of the Great mosque in Yazd, diamond was used in combination with other motifs that in many cases was as the geometric nodes and is not used as a single motif.

Another geometric which has triangle shape is known as the "Congress". This motif of architecture is inspired by desert areas and on the wall of caravanserais towers and decorates the edges of the wind towers Yazd. The motif is of the two types of eye and plain woven. Its simple white square in the middle of that motif as the eyes does not exist. Simple example of the motif of Congress can be seen in the border frames in the entrance of the mosque, With the exception that the tiling, the chain of the motif of Congress in a row and runs a narrow margin. But the architecture, the motif of the two triangles together, but mirror with white and brown color scheme can be seen. Frames also have designs and inscriptions in Chinese knot with the shahada expression (Figure 10). 
In tiling, there is another motif known as the "intervention of Congress" that this motif also is common among architects and tiling. Tile building in Iran have used this motif. Although on the edge of the building also was used as a Congress and as rugs and carpets Gabbeh, to a marginal motif, has been used (Mohebbi and Assyrian, 1380). The narrow margin edge of the dome mosque can be seen (Figure 11) that is of the intervention of Congress, and in two colors, white and azure.

This motif is simple in most of the tiles on thin margins. Similarly, the motif of the mosque can be seen in other areas, one of which is the motif of Congress in the combination of tiles and bricks in the courtyard of the mosque, around the south porch is decorated with a congress and diamond print larger and easier than other parts (Figure 12).

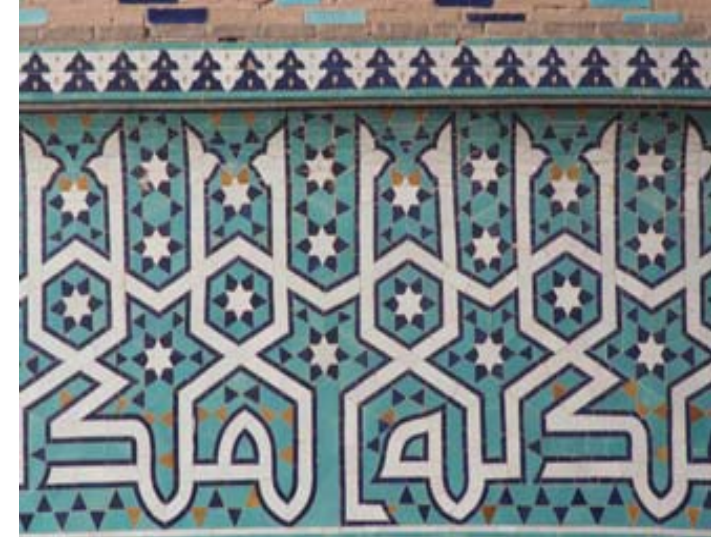

Figure 11. congressional motif interventions, the margin of tiled dome, Great Mosque

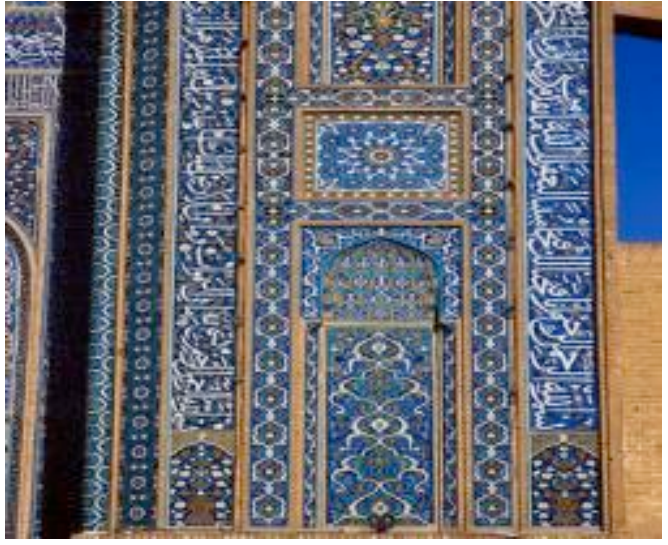

Figure 10. The motif of the triangle, the south porch tiles, Great mosque

Among other common motifs among the architectural decorations and tiles of the Great mosques of Yazd, there is a square-shaped part known as "tamarind". The plan is used in the old traditional Iranian arts (Ardekani, 2000: 7). This candy in Tehran and other cities to is known as "Sugar Cheese".The motif of the tiles are always on the the narrow and white edge and in similar cases in the interior of the domes and arches margin. The motif is mostly used in turquoise and azure colors and the brick surfaces (Figure 13).

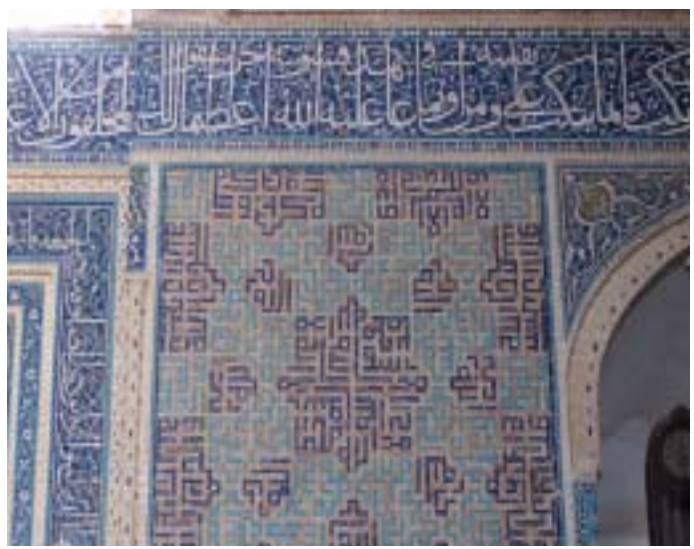

Figure 13: square motifs, vault views in the margin of the dome, Great Mosque

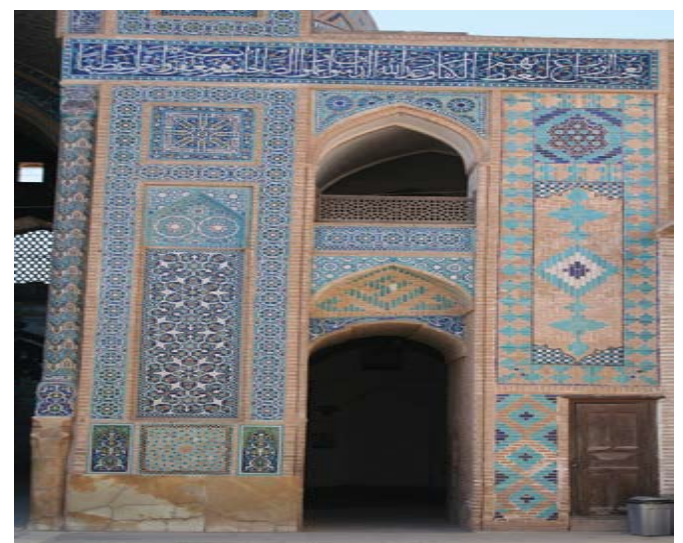

Figure 12: The motif of Congress, intervention, and tiling of the floor space around the south porch, Great Mosque

Along with geometric patterns, broken lines are among the decorative motifs which masters call them the "necklace" and this motif has been affected by the brick works of Yazd architecture (Ardekani, 
2000: 7). These lines and shapes can be seen in white and black in the top edge designs of tiled dome which are repeated periodically around the dome (Fig. 14). Another type of broken lines, the borders are used as materials or Kofi Mqly is inspired by the lines which was also used in architecture and the decorative border tiles called "marginal motif" is executed. An example of this motif in the mosque dome and rim attached to the dome, the motif which is similar to the building line, especially with lower margins and other motifs names of Allah, Muhammad, and Ali in the construction line and tile blue line has created a combining beauty (Figure 15).

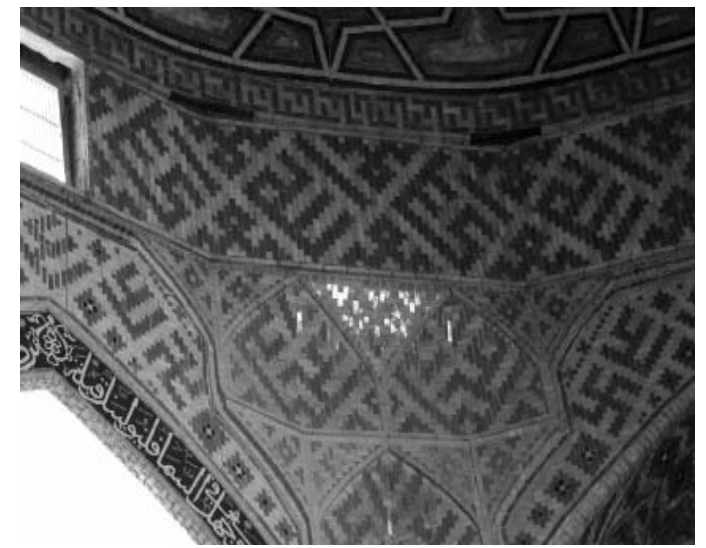

Figure 15: The broken lines at the edge connected to the interior of the dome, Great Mosque

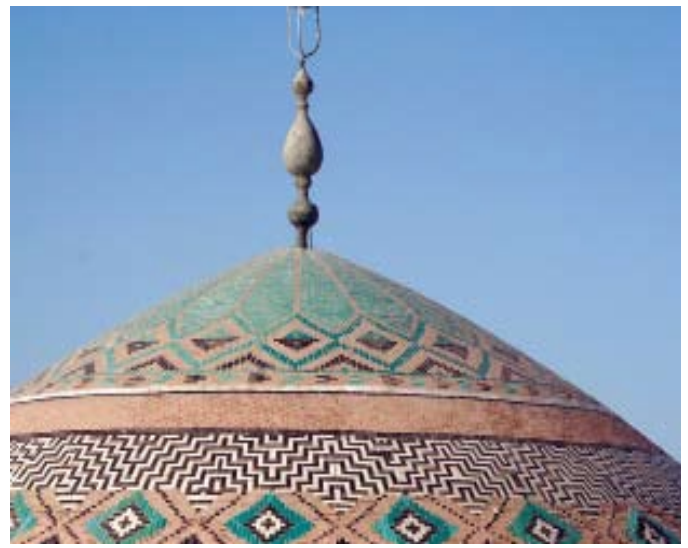

Figure 14: the broken lines, the top edge of the dome, Great Mosque

Other motif shared among the designs of architectural and tiled decorations of the Great mosque in Yazd is the crux or sun wheel which has a long history among human civilization. It can be said that the starting point for more designs and motifs is crux (Mohebbi and Ashori, 2000: 50). The crux which move in four directions in the center and creates various shapes with various movements eventually lead to the octagon.

The power and simplicity of the motif is the main cause of attracting human attention and its transcending during the human history. In the Islamic period the motif as well is glaring with a significant diversity in all aspects of art and everyday life. Crux motif with these motifs can also be seen in tiles of the great Mosque. An example of this motif can be seen in the mosaic tiled entrance of the mosque in white, blue and turquoise color implemented among other designs (Figure 16). Further, the crux motif has created a beautiful combining with the name "Ali" in the building line and the diamond tiles under the doom space (Figure 10).

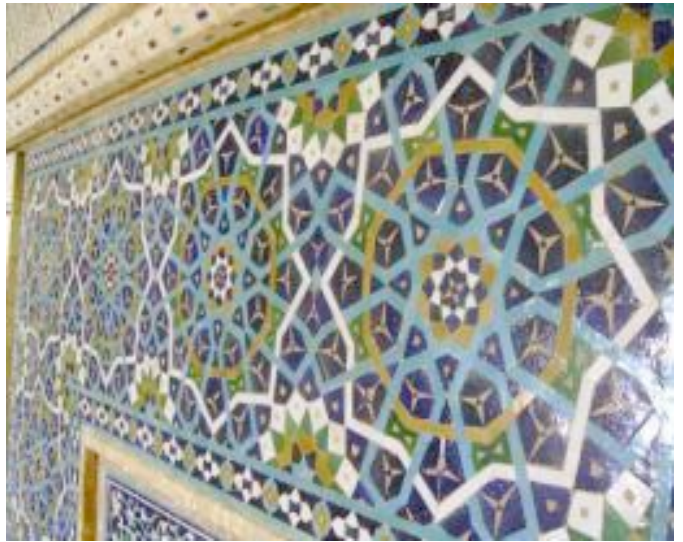

Figure 17. octagon motif, part of the

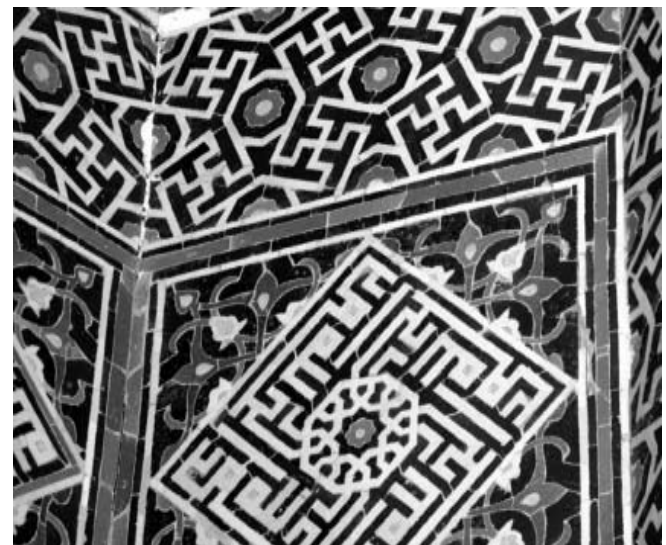

Figure 16. The vrux motifs, views of the 
interior tiled walls of the dome, Great entrance arch, Great mosque Mosque

There are more complex geometric designs and diversity by implementing a brick or a combination of brick and tile (stronghold) in Great Mosque of Yazd. Coarse or fine-scale geometric arrays into thin strips on the porch and entrance are more common and are minimized within the sanctuary. The octagon motif and the symbol of sun in the south porch and the entrance of the mosque is widely used in Islamic art and have numerous meanings and concepts (Figures 18 and 19) including "imaginable as a symbol of divinity and oneness light" (Khazayi, 2002, p. 132).

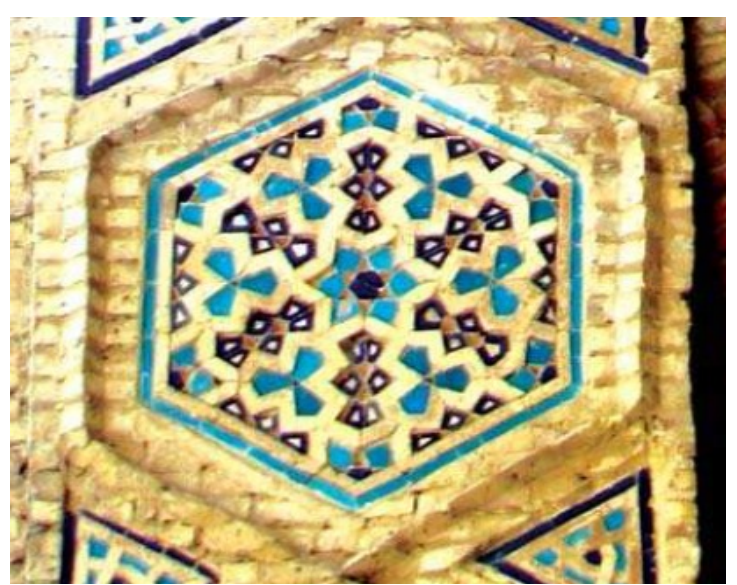

Figure 19. hexagonal sun motif with stronghold bricks in the southern entrance of the Great Mosque

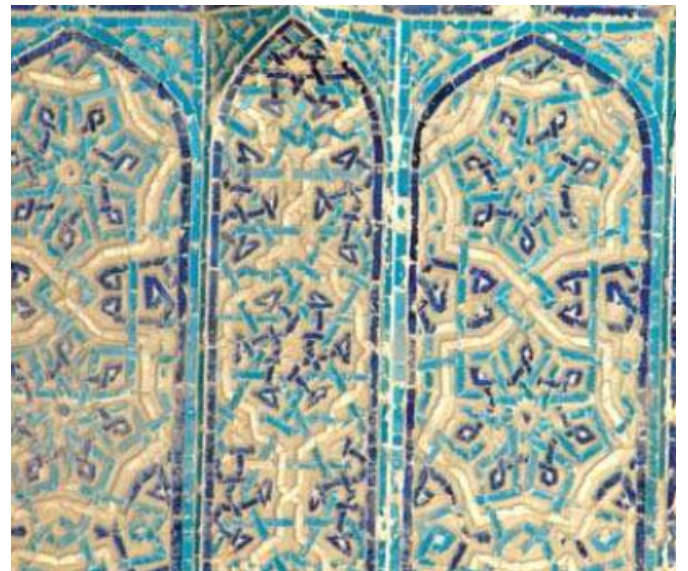

Figure 18. octagon sun motif with stronghold bricks in the northern entrance of the Great Mosque

Other geometric motifs (Figure 20) in the Great mosque include the star crux motifs (it is not quite similar crux but is affected by it). "Crux has four vertices. Number four has always been respected before and after Islam and has been the number of evolution and completeness with with balanced and strong character which has been coordinated with the visual power of crux. Artist has completed the octagon motif by continuing the broken the lines of the crux "(Shayestehfar, 2011, p.102).

"One of the characteristics of Iranian culture is the symbolic nature of the colors, so that each color has a spiritual meaning" (Ardalan, 2001: 2). From among the spectrum of the blue, two colors of turquoise and azure are used in the Great Mosque of Yazd. "Azure is the color the archetype world and symbolizes the size and vastness of the heaven. Turquoise blue is the relaxing color and always refers to the inner world. It has a lot of power in nature and is a color that can be seen at any time in nature and only its light changes" Mesdaghian, 2005: 92).

Also, the observance of certain principles of aesthetics (such as, balance, rhythmic repetition in striking geometric designs) is considerable. The principles for using colors in the decorative array of Great Mosque of Yazd will be assessed and investigated in various decorative forms in the following. The examination of the decorative array developments show that the simple designs based on basic geometric shapes such as squares and polygons with symbolic concepts and colorless concepts in over four hundred years at the Grand Mosque of Yaz have changed into the complex designs based on the combination of simple patterns as nodes and sun with mystical concepts by application of blue.

Another patterns and motifs which are used in th architecture of the buildings called as an architectural array and decorative elements and widely implemented is the octagonal sun. in the Islamic decorative architecture, octagonal sun is one of the geometric patterns in implementing the decoration of the buildings. Along the lines of this motif, and many motifs have been established and the artists has had many choices in the development and continuation of motifs. An example of 
octagonal sun has been implemented in part of the tiling in the dome of the Great Mosque on the part of the interior walls with mosaic tiling. Tile designs are a combination of several octagonal suns in different sizes (Figure 20), which have been created by continuing the white and turquoise blue lines in the background.

Another example of this octagonal sun can be observed in the turquoise tiling around the south porch of the mosque. The motif which has been drawn in the square frame and the lines of it in the white ends with the inscription on the frame. Inside the sun, there is a small arabesques motif implemented which at first sight is similar to the word Allah. Around frame also there are motif of octagonal sun which has been implemented periodically (Fig. 21).

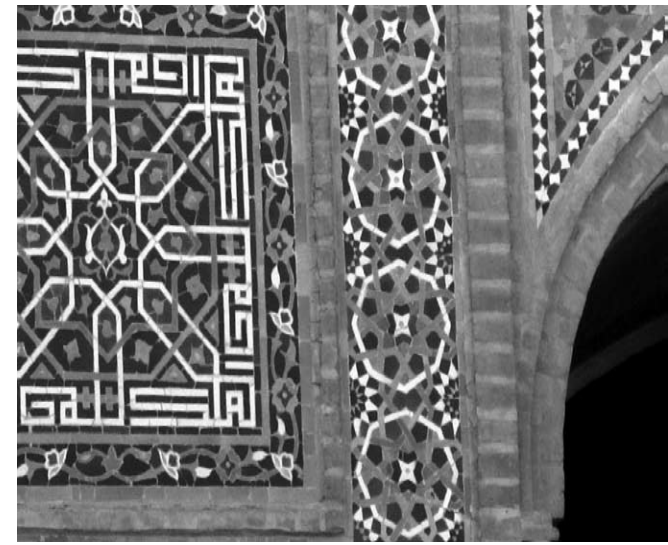

Figure 21: octagone motif in tiles around the south porch, Great Mosque

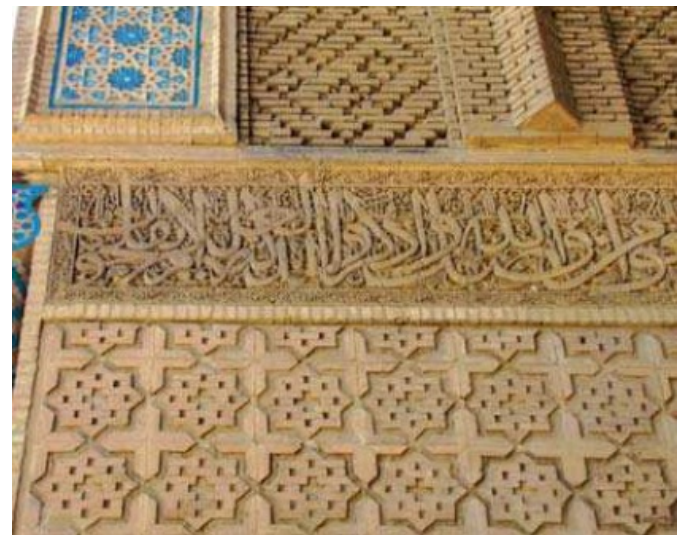

Figure 20. Star crux motifs with brick in the southern porch of the mosque

In a brief summary of the geometrical motif used in the tiles of the Great mosque in Yazd, one can understand that the designs used in tiling have been more repeated as the single motifs together, while geometric patterns in tiles are used in combination, so that repetition of them together have been developed other designs.

\section{PLANT MOTIF OF THE ARRAYS}

The most delicate form of life is associated in the plant motifs and therefore they are present in holy places, and have been developed during the time. Perhaps the sense of freshness, vigor and vitality in the space of the mosques with plant motifs is one of the reasons for its application. From another perspective, because heaven has been accompanied by the pictures of trees with water beneath them, using an array of plant motif is the association of heaven. Moreover, "the hot and dry climate (such as Yazd) is more interested in the use of plant motifs and visual elements are inspired by nature so that nature is dry and your uniform, airy delicate and beautiful flowers, abstract mixed Vjlvh of the infinite beauty of God reflected in the viewer "(Shayestehfar, 99: 1390). "Having this array means diverse and hard enough concepts. They often break the monumental logic and approaching and consequently their interpretation are accompanied by uncertainty" (Grabar, 1992: 210). As mentioned, the plant motifs used in tiles of the Great mosque in Yazd are the motifs taken from flowers, plants and nature such as arabesques and Hatay which have been used as breaks and geometric shapes in Great mosque of Yazd. One of these motifs includes the multi-side flower motifs that are implemented at border. Examples of this motif are the five-and six-pointed flowers have been implemented in the tiles of the entrance with mosaic tiles along the flowers of Shah Abbas mosque and arabesque on blue background (Figure 22).

Octagon flowers including eight-pointed sun have been very applicable in the tile work. One of the motifs called cut octagonal is one of the motifsgreatly used in the margin and is very similar to the regular eight-pointed flowers. An example of the eight-pointed flowers in combination with arabesque motifs can be seen in the tiling around the mosque entrance (Figure 23) which has been implemented as part of the Sun within which there are other eight-pointed flowers. 


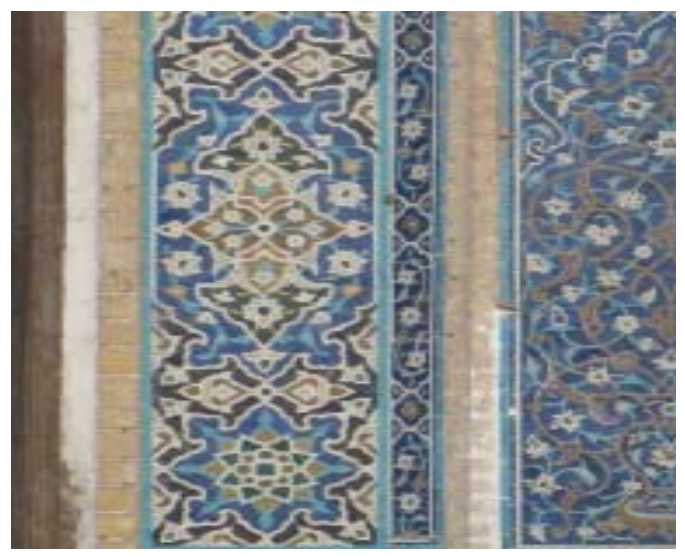

Figure 23. multi-pointed flower,, tiles around the entrance, Great Mosque

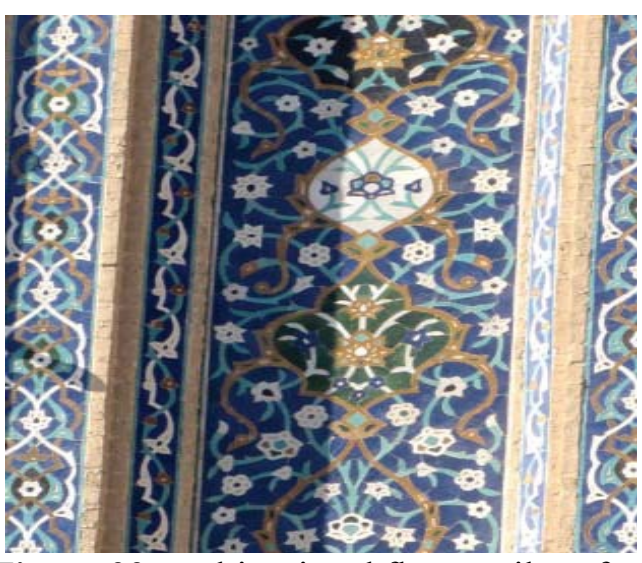

Figure 22. multi-pointed flower, tiles of the entrance, Great Mosque

Arabesques are one of the plant designs that are used in the decoration of buildings. The motif that creates combined patterns with an infinite set of functions with its curves and bends and because of the flexibility and diversity has been considered by many artists in different fields of art. Arabesque motif has been very applicable in tiles of the Great mosque in Yazd. One of these samples is the repeation of the single arabesques in the entries of the columns of the southern portico (fig. 24) which has been implemented in white, blue, turquoise, green and khaki colors for seven and eight repetitions.

Another motif which has been used in the toles is known as vase and similar to the combination of the arabesque. An example of this motif is so that leaves the motif are like the arabesques from the two parties and is used in the entrance of the Great mosque (Figure 25).

Arabesque combination in this way has been implemented in white on the turquoise blue background.

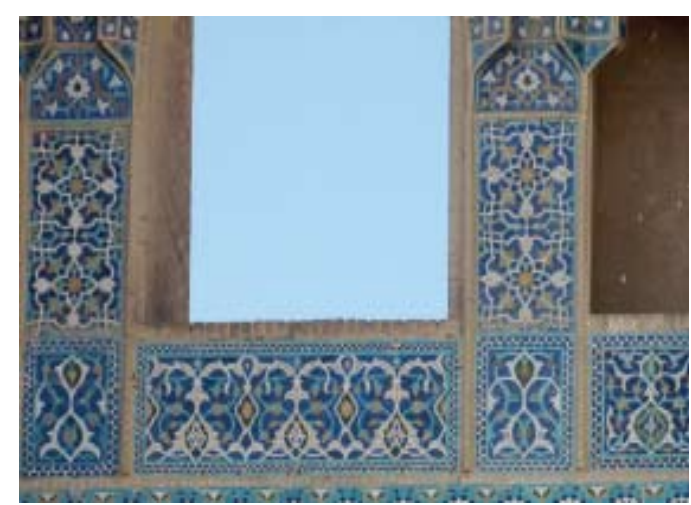

Figure 25: arabesque, tiles of the entrance, Great Mosque

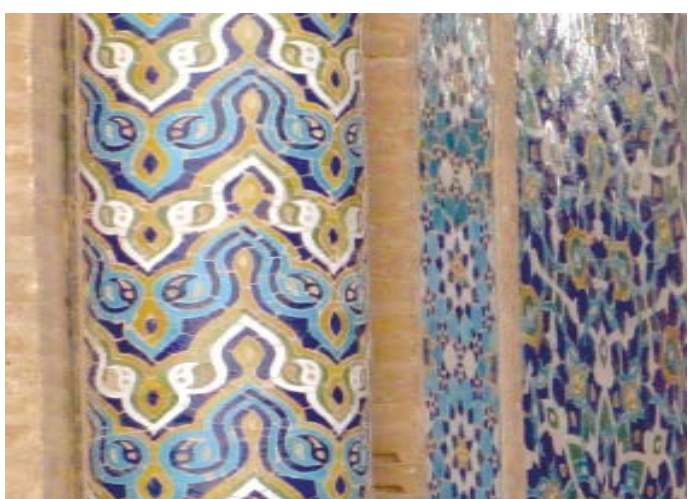

Figure 24: tiles of the south entrance porch columns, Great mosque in Yazd

Earlier it was mentioned that the circulation and rotation of arabesques has created many motifs and nodes. An example of it which is more similar to the node, can be found in the frame tiled from the integration of the arabesques and geometric tile work around the mosque entrance, so that the motifs of arabesques are entwined in white on blue background and in the center of the frame have appeared in the form of sun and in the four corners of it as small Quaters (Figure 26). 
Finally, it can concluded that the plant motifs in the array of Great mosque of Yazd show that the initial plans for the array were based on natural shapes to induce a feeling of vitality and after four hundred years, these arrays have been changed into more abstract patterns of plant mostly in th form of arabesques with limited applications.

\section{STURCTURE OF THE ARRAYS}

In this section, the functional structures in tils of the Great mosque of Yazd are reviewd, the most important of which are the altar and flower motifs. Architectural design of the altar is used in the porch and multiple arches of the mosques and places of pilgrimage and is rooted in the ancient rituals of Iran (Mohebbi and Ashori, 2000, p.46). This design of this pattern is actually a duplicate of the plan altar which are organized at a pace similar to each other in an array so that they have little margin for each row, and then altars are followed and certain motifs are used at intervals (Mollazade and Mohammadi, 2000).

In the altar design, a set of motifs including crux, diamond, square, quarter and eight-pointed flowers and coil forms has been implemented at the top of the altar, which is similar to the single arabesque. A similar example of the altar can be found in the mosque entrance arches, the arch of which in the smaller section is influenced by the entrance Mogharnas or altars and the bottom is covered with arabesque designs windings (Figure 27).

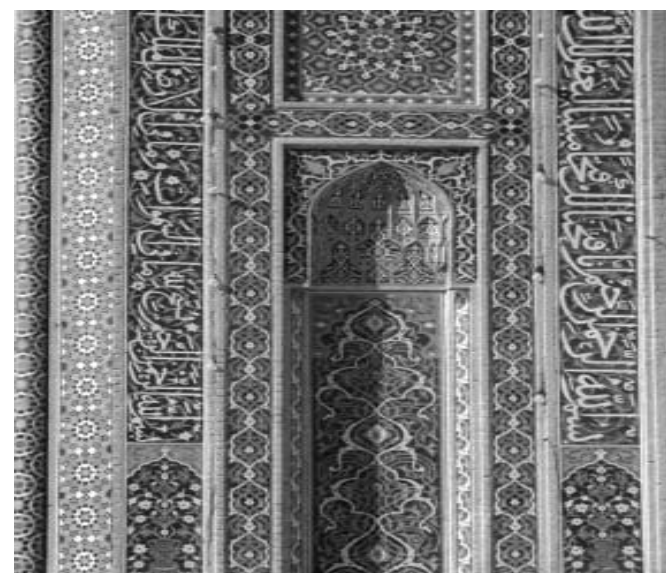

Figure 27: the motif of altar in the vault entrance, Great Mosque of Yazd

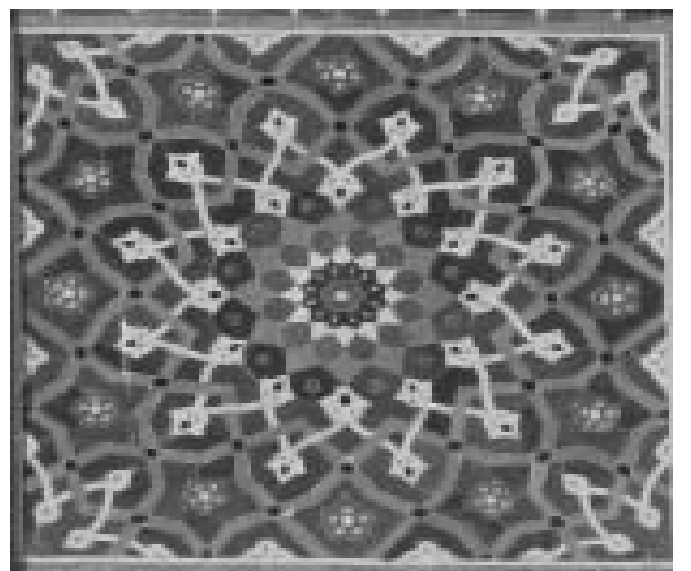

Figure 26: The motif of Arabesque (node), entrance, Great Mosque of Yazd

The most central part of the mosque is its altar, where, as noted earlier based on the literal meaning of the altar (Fig. 28) is the place for the war of evil and passion. Thus, the altar of the Great mosque in Yazd is one of the elements affecting the arabesque designs of Yazd Mosque. The altar area is covered with mosaic tiles and arabesque in Azure which has created a beautiful look on the mosque's dome. The space above the altar is covered with twists and turns of Hatay motif.

Other designs and structures used in tiles of the Great mosque of Yazd is the design and construction of the vase. The plan is very similar to the structure of the altar; the general plan of both is one with the difference that the vase motif stands in the central area along with many flowers that have come out of it. An example of this plan can be seen in a part of the tiles in the entrance of the mosque (Figure 29) on top of which some inscriptions of Quran are written. 


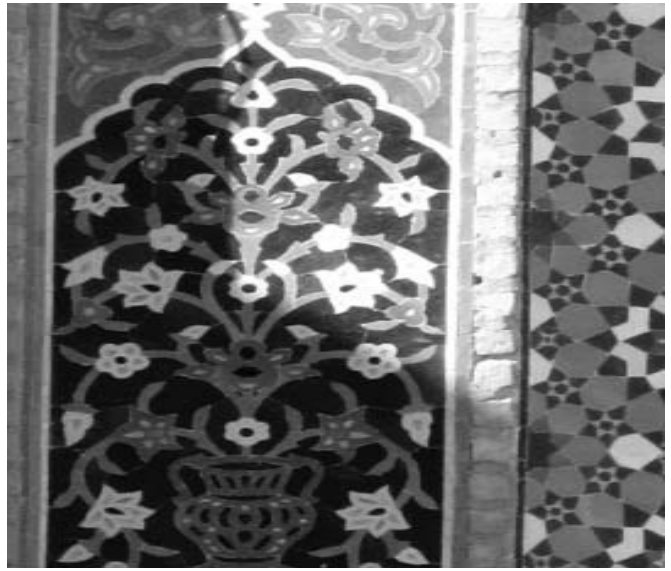

Figure 29: The vase motif, the tiles of the entrance, Great Mosque of Yazd

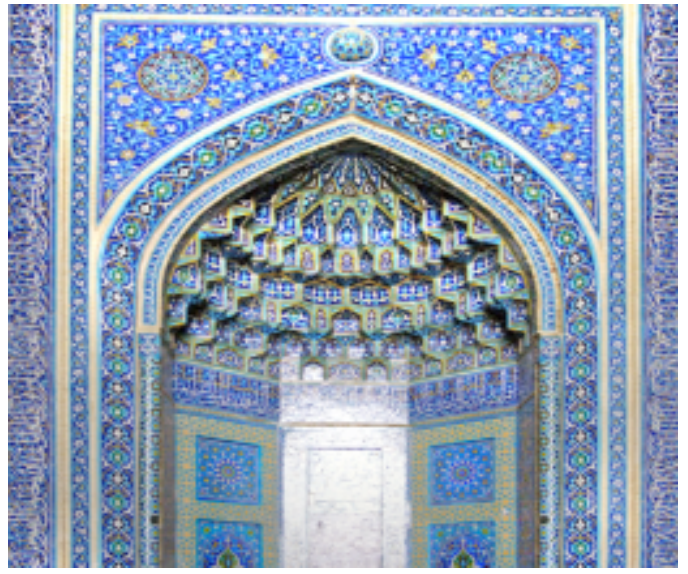

Figure 28: Great mosque of Yazd

\section{ARRAY OF CALLIGRAPHY AND DECORATIVE LINES}

\section{KOFI BANAIEE SCRIPT}

Decorative scripts of the Safavid era are generally Kufi Banaiee and Thuluth script which have been considered due to spiritual and religious aspects as well as the designers of these scripts. While in the Qajar era with the development of hieroglyphics more scrolls were written with this script, one of the features of Kufi banaiee scripts in the Safavid era was the emphasis on geometric diamond and square motifs as a the frame or as a single geometric motif in the composition that is well reflected in the decoration of the Grand Mosque of Yazd.

Great Mosque is generally in the eastern and western sides of the building and the inscriptions on the second floor rooms and generally include a combination of several examples of the implementation of Kufi script in various colors such as white and yellow in yellow and black decorative frames decorated with arabesques, quarter and geometric and background bricks with different color (Figure 30) (Sharifinia, 2002, 137). 


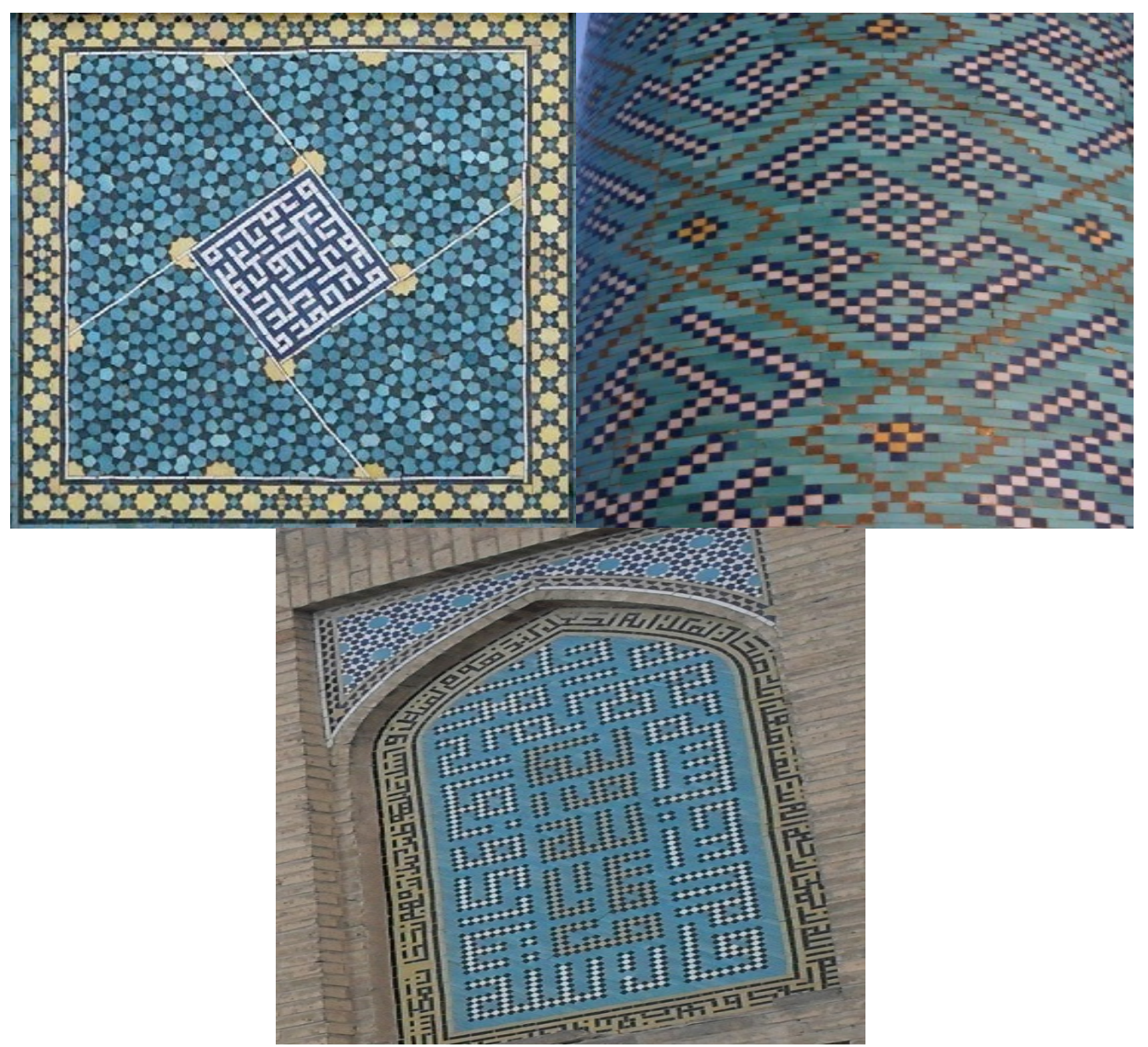

Figure 30: Kufic script of the mosque

\section{THULUTH SCRIPT}

Script as a non-visual element is composed of "the vertical, horizontal and circular elements each of which has a symbolic expression. For example, letter aliph due to its vertical form is the symbol of the glory of God and the Almighty origion that everything derives from it "(Nasr, 2011: 38). The vertical strain of the letters in the style of the Thuluth script in the main scrolls of the mosque in Yazd was previously shown in Figure 11. Scrolls are used in the form of individual words or phrases in mosques to recall the commitment of Muslims to the speech of God and remember Him (verses and describing the names of God), praising the Prophet and the Imams (prayers).

In addition to increasing the spirituality of space, thuluth scripts give an image of the domination of the dominant religion (Shia or Sunni). In addition, thuluth script is used in Great Mosque of Yazd on the back side, the entrance, the Dome and the like. Thuluth script used in this mosque has an elongation and height, the compression of which causes difficulty in reading it (Figure 31). 

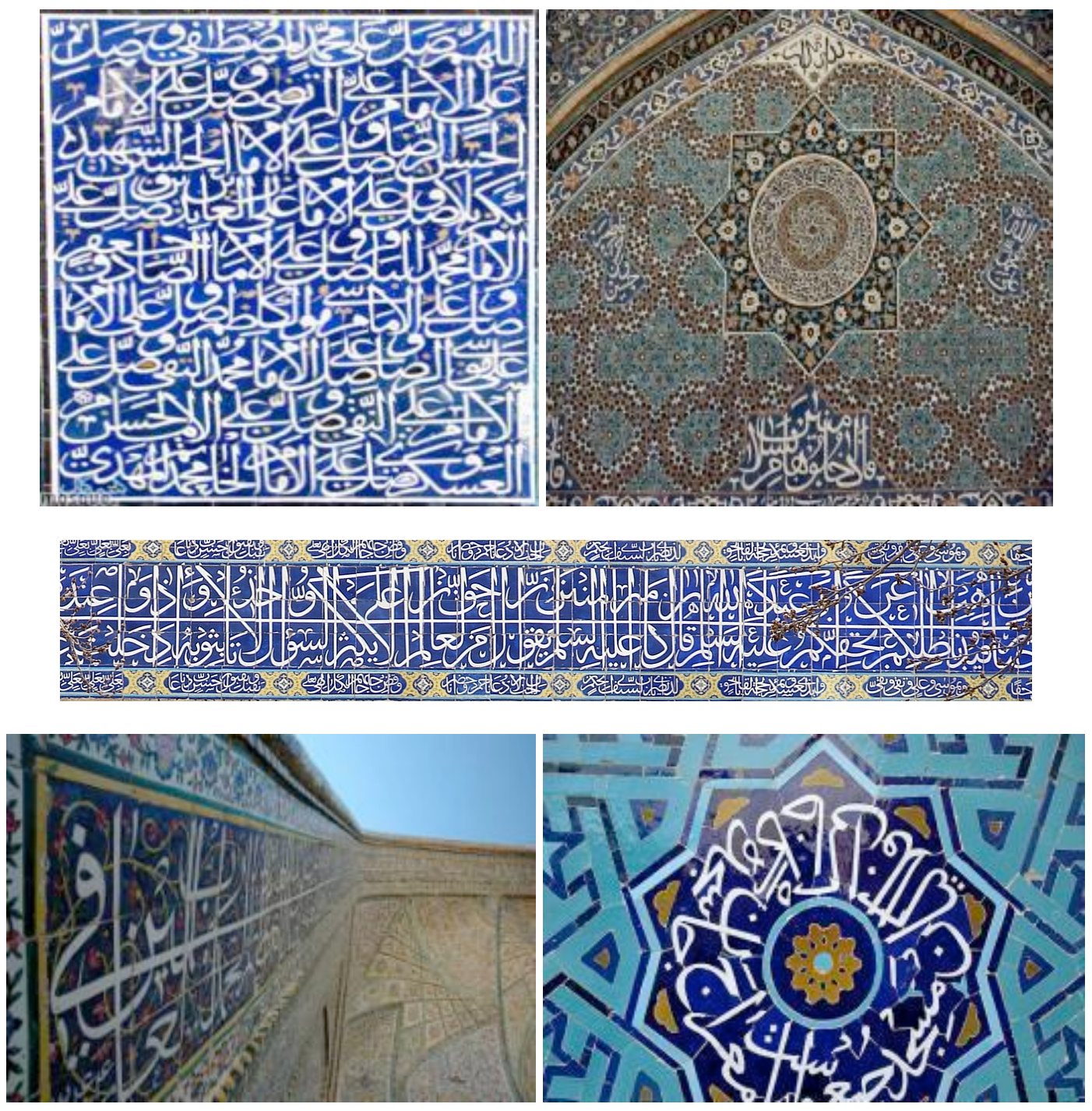

Figure 31: Thuluth script of the edge of the porch and the altar margin on the dome of the Great Mosque

The background of Thuluth in the monument is generally free of decorations and script has been used alone as pure. Empty spaces are filled with writting vowels and in some cases plant motifs with light colors were used in the context of the scrolls. Also, the scripts of both monuments have been implemented in white or yellow on the blue background. Accordingly, the Thuluth script in this monument has been used for the divine names, verses, chapters and themes of the Quran.

\section{NASTA'LIQ SCRIPT}

Nasta'liq script which is a purely Iranian hieroglyphics is the symbol of unity and a sign of the Iranian cultural identity against the influence of Western art in the Qajar era. Although the script was common at the beginning of the Safavid era, just a few cases of this script can be seen in the Great mosque in Yazd which are set in the frames apart and on a line (Figure 32). However, this script has been frequently used in the next period in the Great mosque.

For example, at the top of the walls of the south porch in the mosque, this script is used within decorative frames and as the cornice mosque blue background is written with white with decorative elements around them like each other. These texts are written in praise of the Prophet (PBUH) and Imam Ali (AS). Another use of Nastali'q is in the Farsi translation of hieroglyphics in the mosque at prayer, an example of which can be found at the northern entrance porch. Further, this script is used 
for writing Hadith, the Holy Names, signatures by master craftsmen, $f$ the date of construction and its description (Figure 32).

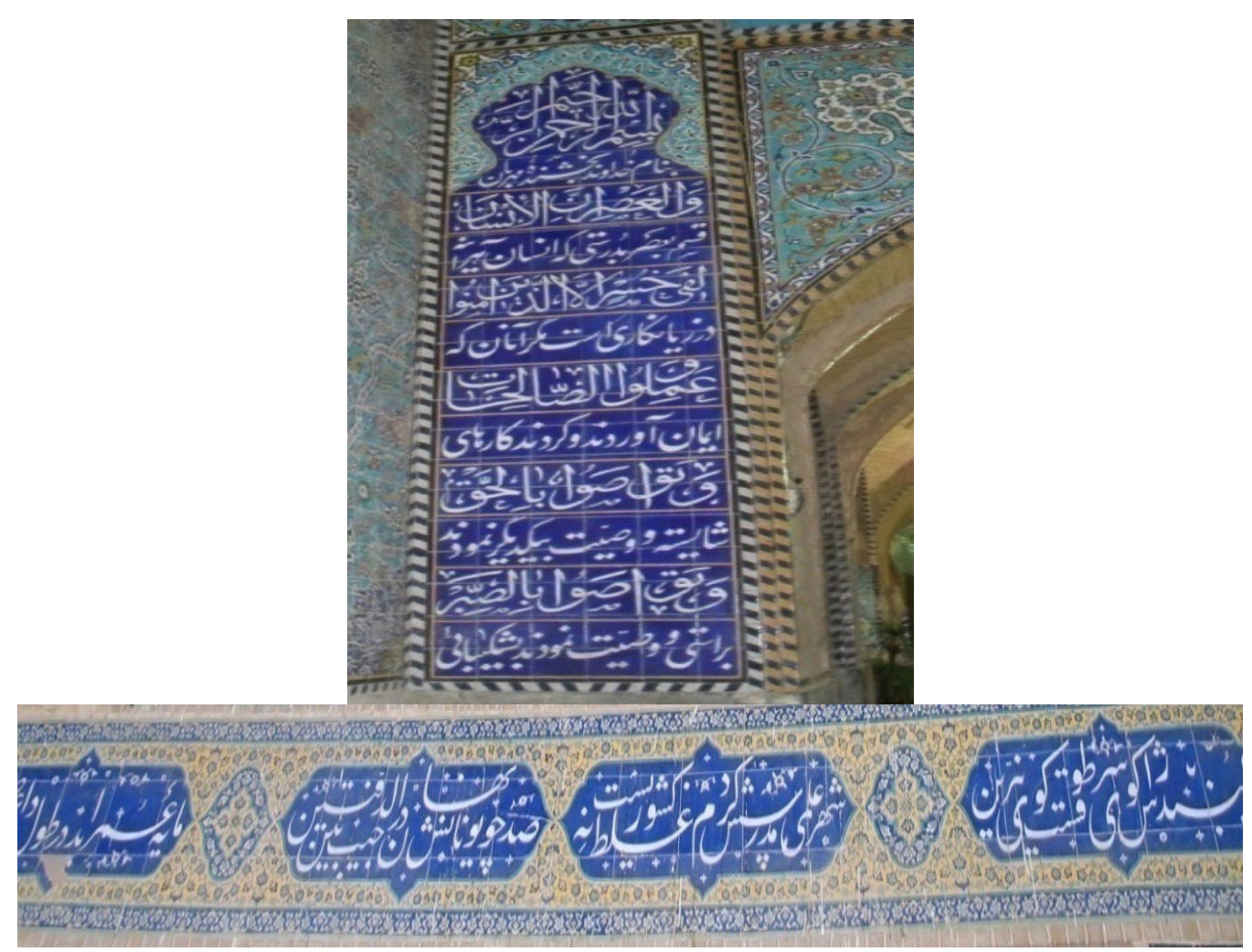

Figure 32: nasta'liq script in the great mosque of Yazd

\section{CONCLUSION}

In this paper, using bibliographical references, and through field research the decorative arrays of the mosque have been analyzed and examined looking at the Islamic decoration of the mosque. Then, the architectural ornaments and manifestations and effects on the physical architecture of the mosque such as brickwork, stucco, tiling, and mogharnas are discussed and following, the scheme and the motif of the Great mosque in Yazd have been introduced and historical developments of the monument has been investigated during the second half of the third century AD. In the next part of the research, matching between the color and decorative array of the Great Mosque in Yazd was examined and in this concept with field observations, the most important arrays used in the Great Mosque of Yazd including the decorative geometric designs and an array of plant and structural framework as well as an array of designs and decorative scripts with an emphasis on three scripts of Kufi calligraphy, Thuluth and Nastali'q were analyzed and their changes were reviewed during the four-year period.

As a summary conclusion and based on surveys conducted regarding the decorative array of geometric patterns, plant, architecture and calligraphy on the walls and tiles of the Great mosque in Yazd are as follows:

Regarding the decorative array of plant motifs in the Great mosque of Yazd, it can be found that the initial plans for the array were based on natural shapes to induce a feeling of vitality and after four hundred years, these arrays have been changed into more abstract patterns of plant mostly in th form of arabesques with limited applications.

The examination of the decorative array developments show that the simple designs based on basic geometric shapes such as squares and polygons with symbolic concepts and colorless concepts in over 
four hundred years at the Grand Mosque of Yaz have changed into the complex designs based on the combination of simple patterns as nodes and sun with mystical concepts by application of blue.

In the Great mosque, some plant and geometric designs each have been separately identified and can be seen in a state of simplicity and spiritual in the decorative tiles. In some cases a combination of different designs for a multitude of colors and designs without a specific purpose with the details and intricacies has been designed on the wall surfaces.

In Great Mosque of Yazd the use common use of geometric and traditional herbal patterns in the Iranian arts has been decreased and instead among the arabesques arms, the naturalist motifs such as natural flowers, architecture landscape, and nature-oriented image have been used. So, perhaps it is more logical to consider the integration of the two systems largely unintentional and the result of the influence of long-standing tradition on the one hand and the lack of sufficient knowledge of scientific principles and art academies on the other hand.

In addition, the analysis of the decorative script arrays in Great Mosque of Yazd showed that the majority of calligraphy scrolls of the mosque are Thuluth and Kufi with Quranic themes and verses, suras and hadiths that are difficult to read according to kind of their implementation. The use of hieroglyphics for translating the prayers, traditions, Holy Names, signature of the master craftsmen, building and construction date are the other dominant scripts of the monument.

\section{REFERENCE}

Afshar, I., (1975), mementos of Yazd, National Heritage Association, vol. 2, Tehran,

Ahmadi Maleki, R., (1998), forms and symbolic roles in Iranian mosques, a publication dedicated to the immortal legacy, the sixth year, serial number 22, pp. 110-116,

Alizadeh,A.(2003). Excavations at the Prehistoric Mound of ChoghaBonut Khuzestan, Iran,seasons1976/77, 1977/78 and 1996 ,Chicago: The Oriental Institute of Chicago Publications,p154.

Ardekani Ali Mohammadi, J., (2000), research on Yazd rugs, p. 7

Blair, S. Bloom, J. 2007. Islamic Mongols: From the Mongol Invasions to the Ilkhanids, in Islamic Art and Architecture. Ullmann Press.

Blair, S. Bloom, J. 2009. Stucco and plasters in Islamic lands. Oxford University press.

Brend, B. 2007. Islamic Art. the British Museum Press.

Burckhardt, T., (2006), Islamic art, language and expression, translation M. Rajab Nia, Tehran: Soroush,

Chiti, M., (2000), studying the graphic motifs from the Seljuk mosque in Yazd inscriptions to the Timurid, graduate thesis, Graphic Design, Supervisor: Mohammad Khazaei, Tarbiat Modarres University, Faculty of Arts,

Chiti, M., (2000), examining the graphic motifs inscriptions of the Great mosque in Yazd from the Seljuk to the Timurid, graduate thesis, Graphic Design, Supervisor: Mohammad Khazaei, Advisor: Hasan Ansari, , p. 18.

Esfanjari Kenari, I., (2006), Meybod; the city it is, Tehran, cultural heritage and tourism and cultural heritage database

Golshan, S., (1998), the first buildings Great Mosque of Yazd and the history of the Great Mosque of Yazd, general journal, Journal of Architecture and Urban Planning, No. 26, p. 109,

Haji Ghasemi, K., (2004), Ganjnameh, mosques, Tehran, Martyr Beheshti University, School of Architecture, Aperture, pp. 16-17,

Hall, J., (2001), Dictionary of graphical symbols in the East and the West, translated Roqieh Behzadi, Tehran, contemporary culture, 1380.

Jandaghi Yazdi, A., (1998), Mosque of Yazd, Yaghma, No. 2,

Kiani, Y., (2000), Iran Islamic architecture, SAMT, Tehran,

Kiani, Y., (2007), architectural ornaments of the Islamic era, publications of the Cultural Heritage Organization, Tehran,

Kianmeher, G and Khazaei, M. (2006), numerical concepts and words in the art of Chinese knot of Safavi era, Art Monthly, pp. 26-39, 
Laleh. Bakhtiar. 1960. Sufi. London: Thames and Hudson. whelan . E. 1986. "The Origins Of The Mihrab Mujawwaf: A Reinterpretation", International journal Of Middle Est Studies, 18, 2: 205-223.

Lawrence A, Hardie(1967).The Gypsum-Anhydrite Equilibrium at One Atmosphere Pressure, The American Mineralogist,vol 52, p18.

Makinejad., M., (2008), history of Iranian art in the Islamic architectural decorations, Tehran: Center for Research and Human Development,

Malta da Silveria, P.Veiga, M. de Brito, J. (2007). Gypsum coating in ancient buildings, Construction and Building Materials,21: 126-131.

Mass, J.1. (1999). Instrumental Methods of Analysis Applied to the Conservation of Ancient and Historic Glass, in book Conservation of Glass and Ceramics : Research, Practice and Training, James Publication.

Memarian, GH, (2005), the study of the theoretical foundations of architecture, student Soroush Publications, Tehran,

Memarian, GH, (2008), Iranian architecture, knowledge Soroush Publications, Tehran,

Middendorf. B.Budelmann. H, 1995 in: Proceedings o f the Fifth Euroseminar on Microscopy Applied to Building Materials, Leuven, Belgium, vol. 40, September 1 4e15.p 23.Moisset .J.1985.

Mohebbi, O., and Ashori, M., the symbols and motifs in historical rugs, ibid, pp. 53-52.

Motamedi, m., (2004), tiling in Safavid era and its impact on contemporary art, Supervisor: Ali Hatem, Advisor: Amirashrf Aryanpour, master's thesis research, art, School of Art and Architecture, Azad University, Central Tehran Branch,

O'Kane, B. 1992. "Natanz and Turbat-I Jame: new light on fourteenth century Iranian stucco", Studia Iranica, XXI, 21: 85-92.

Peterson, Samuel R. 1977. The Masjid-i Pā Minār at Zavāreh: A Redating and an Analysis of Early Islamic Iranian Stucco. Artibus Asiae.

Pirnia, M., (1995), Islamic architecture, editor Memarian, GH, University of Science and Technology, Tehran,

Pirnia, M., (2007), the style of Iranian architecture, Soroush knowledge, Second Edition, Tehran,

Pirnia, M., (2010), the style of Iranian architecture, editor Memarian, GH., architect inquiring publication, Tehran,

Pope, A. U. 1934. The Historic Significance of Stucco Decoration in Persian Architecture. The Art Bulletin.

Pope, A. U. 1973. vol. III. A survey of Persian Art. Oxford University Press.

Salari Taleghani., M., (2006), comparative study of Safavid and Qajar era tile designs, Supervisor: Hussain Sultan Zadeh, Advisor: Eskandar Mokhtari , master's thesis research, art, School of Art and Architecture, Islamic Azad University, Central Tehran Branch,

Schmidt, E. (1939). The Treasury of Persepolis, Chicago: The Oriental Institute of Chicago, No. 21,p 53.

Sharifinia, S., the geometric aesthetic with an emphasis on Chinese knot in the mosques of Yazd, Supervisor: M. Ansari, Advisor: M. Shayestehfar, a Master's thesis research, art, School of Art and Architecture at Tarbiat Modarres University

Wilkinson, Charles, K. 1986. NISHAPUR, Some early Islamic buildings and their decorations, The Metropolitan Museum of Art, New York.

Yousefi Kiani, M., (1995), history of art and architecture in the Islamic period, Tehran, research organizations and universities to develop human sources (SAMT), pp. 74-75

Zamani, A., (1993), decorative Kufic script in Islamic monuments of Iran, art and people magazine, No. 138, Tehran, Ministry of Culture, p. 12.

Zeymal, Ye.V. 2008. History \& uses of stucco and plaster in central Asia. Oxford university press. 